\title{
APLIKASI METODE DISKUSI DALAM MENGEMBANGKAN KEMAMPUAN KOGNITIF, AFEKTIF DAN SOSIAL DALAM PEMBELAJARAN SAINS
}

\author{
Dwikoranto \\ Email: dwi_bsc.saja@yahoo.co.id \\ Physics Department, Faculty Mathematics and Science of The State University of Surabaya (UNESA) \\ Jl. Ketintang, Surabaya 60231, Indonesia.
}

\begin{abstract}
ABSTRAK
Metode diskusi dapat diterapkan dalam pembelajaran sains untuk mengembangkan kemampuan kognitif dan afektif siswa. Juga dapat melatihkan keterampilan social, sifat toleransi dan kemampuan analisis kritis dan kreatif dalam memecahkan suatu masalah. Diskusi dapat pula dipergunakan untuk mengawali inkuiri dalam sains dan mengembangkan keterampilan memecahkan masalah, merumuskan suatu hipotesis, menguji jawaban yang bersifat tentatif, mencari solusi dan generalisasi. Keberhasilan suatu diskusi bergantung pada fleksibilitas guru dan kebijaksanaan guru, kemampuan guru dalam mengorganisir jalannya diskusi, keluasaan ilmu guru, aktivitas siswa, pengaturan lingkungan fisik, dan penjadwalan. Hambatan terhadap salah satu faktor tersebut akan mengurangi keefektifan diskusi. Pemilihan topik-topik yang menarik, kontroversial dan isu yang sedang berkembang mendukung keberhasilan dalam diskusi.
\end{abstract}

Keywords: metode diskusi, kemampuan kognitif, afektif, social, pembelajaran sains 


\section{Pendahuluan}

Kemampuan daya pikir dan kemampuan afektif dari siswa dapatlah dikembangkan melalui strategi pembelajaran diskusi. Strategi ini dapat dipergunakan untuk memberikan kesempatan kepada siswa mengklarifikasi nilai-nilainya sendiri maknanya nilai yang timbul setelah pemahaman diskusi dilakukan oleh siswa tersebut, dan membuat keputusan yang tepat tentang masalah masalah sosial yang terjadi di dalam kehidupan sehari-hari. Membuat keputusan tentunya setelah melalui pertimbangan dalam diskusi dengan menghitung untung dan rugi sesuatu tersebut, dampak atau akibat yang ditimbulkannya jika sesuatu tersebut dilakukan. (Kardi, 2010)

Menurut Tjokrodiharjo diskusi adalah situasi dimana guru dan para siswa, atau antara siswa dengan siswa yang lain berbincang satu sama lain dan berbagi gagasan dan pendapat mereka. Langkahlangkah guna menyelenggarakan diskusi adalah menyampaikan tujuan dan mengatus setting, mengarahkan diskusi, menyelenggarakan diskusi, mengakhiri diskusi dan melakukan tanya-jawab singkat tentang proses diskusi. (Tjokrodiharjo, 2005)

Diskusi digunakan oleh para guru untuk mencapai sedikitnya tiga tujuan pembelajaran khusus yang penting, yaitu:
1. Diskusi meningkatkan cara berfikir siswa dan membantu mereka membanguun sendiri pemahaman isi pelajaran.

2. Diskusi menumbuhkan keterlibatan dan keikutsertaan siswa.

3. Diskusi digunakan guru membantu siswa mempelajari keterampilan komunikasi dan proses berfikir yang penting.(Tjokrodiharjo, 2000)

Diskusi dapat pula dipergunakan untuk mengawali inkuiri dan mengembangkan keterampilan memecahkan masalah, merumuskan suatu hipotesis, menguji jawaban yang bersifat tentatif, mencari solusi dan generalisasi. Banyak masalah yang muncul di masyarakat yang dapat diangkat dan diselesaiakan melalui proses diskusi yang baik, misalnya masalah polusi yang dihadapi masyarakat perkotaan, baik polusi udara, air maupun tanah. Masalah lain yang aplikatif yaitu kekurangan air bersih pasca bencana stunami di daerah Aceh, dengan mempelajari sifat-sifat air, cara membuatnya, membersihkan air kotor menjadi air bersih dengan memanfaatkan yang ada di alam sekitar, mendaur ulang air laut jadi tawar melalui elektrolisis atau penguapan biasa maka daya pikir siswa akan tertantang mengatasi masalah tersebut. Kemampuan yang dikembangkan dalam proses inkuiri dan penahapannya dapat dilihat pada tabel 1 berikut.

\begin{tabular}{|c|c|}
\hline TAHAP INKUIRI & KEMAMPUAN YANG DITUNTUT \\
\hline 1. Merumuskan masalah & $\begin{array}{l}\text { 1. Kesadaran terhadap masalah } \\
\text { 2. Melihat pentingnya masalah } \\
\text { 3. Merumuskan masalah }\end{array}$ \\
\hline $\begin{array}{l}\text { 2. Merumuskan jawaban sementara } \\
\text { (hipotesis) }\end{array}$ & $\begin{array}{l}\text { 1. Menguji dan menggolongkan jenis data yang diperoleh } \\
\text { 2. Melihat dan merumuskan hubungan yang ada secara logis } \\
\text { 3. Merumuskan hipotesis }\end{array}$ \\
\hline 3. Menguji jawaban tentatif & $\begin{array}{l}\text { 1. Merakit peristiwa } \\
\text { a. Mengidentifikasi peristiwa yang dibutuhkan } \\
\text { b. Mengumpulkan data } \\
\text { c. Mengevaluasi data } \\
\text { 2. Menyusun data } \\
\text { a. Mentranslasilkan data } \\
\text { b. Menginteprestasikan data } \\
\text { c. Mengklasifikasikan data }\end{array}$ \\
\hline 4. Menarik kesimpulan & $\begin{array}{l}\text { 1. Mencari pola dan makna hubungan } \\
\text { 2. Merumuskan kesimpulan }\end{array}$ \\
\hline 5. Menerapkan kesimpulan dan generalisasi & \\
\hline
\end{tabular}

(Gularsa. W, 2008) 
Semakin berkembangnya pelaksanaan pembelajaran berbasis Contekstual Teaching ang Learning maka masalah sosial perlu dimasukkan di dalam pembelajaran sains. Berkaitan dengan hal itu, metode diskusi merupakan salah satu cara untuk bertukar pendapat tentang isuisu sosial dan topik yang menuntut siswa mengambil keputusan dan mengklarifikasi nilai-nilai yang dianutnya. Misalnya dalam pembangunan pembangkit listrik bertenaga Nuklir yang akan dibangun oleh pemerintah di suatu tempat. Siswa dapat mencari referensi yang maksimal tentang apa itu energi nuklir, sumber atau bahan bakar energi nuklir, pola membangkitkan energi nuklir, daya yang dihasilkan, beaya yang diinvestasikan, bahaya yang ditimbulkan dan dampak sosial pada masyarakat sekitarnya. Melalui diskusi, siswa-siswa akan sampai pada pemahaman yang mendalam tentang isu-isu sosial. Dengan mendengarkan nilai-nilai yang dianut oleh siswa-siswa yang lain, dan dengan jalan mengemukakan posisi yang dianutnya sendiri, siswa akan dapat mengklarifikasi nilai-nilai yang dianutnya, dan memahami nilai-nilai yang dianut oleh siswa-siswa yang lain. Disini akan terjadi equilibrium dalam diri siswa. Diskusi tentang isu-isu sosial akan memberi pemahaman kepada siswa tentang diri mereka dan siswa-siswa yang lain, dan mengembangkan kemampuan mereka untuk mengambil keputusan yang bijak mengenai isu-isu sosial dan kaitannya dengan sains. Pada persoalan energi di aatas maka setelah membahas untung dan rugi dengan adanya reaktor nuklir maka siswa akan paham dan memiliki nilai yang dianut dan disinergikan dengan ilmu yang mereka peroleh. Akhirnya dapat mengambil keputusan apakah suatu reaktor nuklir dapat didirikan dalam suatu wilayah atau tidak perlu membangunnya dan dapat diganti dengan yang lain.

Melalui diskusi, guru dapat menugasi siswa untuk menemukan sendiri hal-hal tertentu dengan jalan menciptakan situasi yang memungkinkan siswa bertanya, mengasimilasi dan menganalisis informasi, dan merumuskan sendiri kesimpulan. Metode diskusi memberi kesempatan siswa untuk menemukan sendiri informasi-informasi baru.

Contoh tugas yang dapat disampaikan oleh guru kepada siswa untuk mendorong proses inkuiri siswa timbul:

1. Mengatasi air keruh yang tercemar di perkotaan agar dapat layak untuk jadi air bersih, bukan air minum.

2. Mengatasi kekurangan energi di daerah peternakan sapi melalui pemanfatan kotoran sapi diubah menjadi biogas.

3. Meningkatkan pengisian air pada tambak garam melalui perubahan energi angin menjadi gerak melalui kincir angin tanpa listrik untuk menghemat beaya produksi.

Pakar psikologi terkemuka Piaget dan Brunner dan penganjur penggunaan metode diskusi menyatakan bahwa penekanan penemuan akan membantu siswa mempelajari bermacam-macam cara pemecahan masalah, mengubah informasi agar dapat dimanfaatkan dengan lebih baik, dan membantu siswa agar belajar lebih lanjut. (Kardi, 2010)

Keterampilan guru mengajukan pertanyaan yang baik dapat memotivasi siswa untuk belajar, berpikir, dan menemukan, akan dapat melaksanakan diskusi yang berhasil dan dapat membuat siswa memahami secara mendalam isi topik yang diskusikan (Corebima, 2010). Menurut Bruner, mengajar harus dapat mendorong siswa untuk menemukan sendiri informasi atau pengetahuan yang dipelajarinya. Hal tersebut dapat terjadi melalui diskusi, tetapi siswa juga belajar menggunakan metode penemuan. Melalui diskusi, guru dapat menunjukkan kepada siswa cara memahami generalisasi dan mendalami isi topik yang dipelajari.

Pengalaman yang diperoleh seorang siswa melalui diskusi mempunyai manfaat yang bermacam-macam. Diskusi terbuka antarsiswa dapat meningkatkan sikap saling menghormati, percaya diri, 
saling kerja sama, dan keterampilan berkomunikasi. Disamping itu, diskusi dengan tujuan memecahkan suatu masalah dapat meningkatkan kemampuan dalam berpikir kritis, inkuiri, keterampilan proses, dan kemampuan yang lain (Kardi, 2010). Setelah siswa menyadari bahwa dia dapat menemukan sendiri pengetahuan dan berfungsi sebagai pemikir yang mandiri, dia akan dapat menggunakan metode ini sepanjang hidupnya tanpa bantuan orang lain. Diskusi membantu siswa menjadi pemikir yang mandiri dan konstruktivisme menjadi berlaku.

\section{Diskusi dengan Pembimbing}

Jika kita seorang guru yang membimbing suatu diskusi harus dapat menangani bermacam-macam situasi dengan bijaksana. Adalah tugas guru untuk memilih peserta yang ingin berbicara, apabila banyak siswa yang mempunyai keinginan yang sama. Guru perlu bersikap sabar apabila mendengar komentar sumbang dan tidak relevan yang kadang menyinggung perasaan. Ia harus dapat segera mengakhiri situasi sedemikian itu tanpa marah atau kecewa dan mengarahkan kembali diskusi ke topik yang sedang dibicarakan. Topik erat sekali kaitannya dengan keberhasilan diskusi. Tidak semua topik cocok untuk diskusi kelas. Topik diskusi perlu berkaitan dengan pengetahuan yang telah dikuasai oleh siswa. Dengan demikian siswa akan berpikir kritis dan tidak hanya berspekulasi. Isu-isu yang kontrovensial, dan masing-masing siswa mempunyai pandangannya sendiri, merupakan topik yang sangat baik untuk diskusi. Isu-isu tentang cloning manusia, perilaku menyimpang dalam penggunaan internet, penggunaan dan penyebaran narkoba yang luar biasa, kebiasaan merokok di tempat umum, kejahatan dengan pemanfaatan IT adalah beberapa contoh topik yang baik untuk didiskusikan. (Kardi, 2010)

Topik yang berkaitan dengan fakta yang tidak dipermasalahkan kurang baik untuk didiskusikan, kecuali jika siswa ragu-ragu terhadap fakta yang didiskusikan. Misalnya, tidak akan banyak manfaatnya mendiskusikan sifat-sifat makhluk hidup, jika siswa sudah mengetahui sifat-sifat tersebut. Diskusi semacam ini hanya sekedar mengulang kembali sifat-sifat makhluk hidup, tidak lebih dari itu. Contohnya lagi diskusi tentang pengelompokan benda padat, cair dan gas yang sudah pasti hanya berfungsi untuk penegasan kembali, lain lagi bila siswa disodori satu wujud benda lagi yang terletak antara cair dan padat yang kita kenal sebagai gel. Misalnya wujud silikon untuk mempercantik diri, agar-agar makanan yang telah dimasak.

Kita sebagai guru seringkali dihadapkan pada masalah yang berkaitan dengan jawaban siswa yang tidak relevan dan seenaknya saja. Dalam situasi yang sedemikian itu, sebaiknya guru menanggapinya dengan serius. Kadangkadang siswa menjawab tanpa berpikir, yang sepintas lalu jawaban tersebut tidak relevan dengan yang sedang didiskusikan. Meskipun tidak relevan, guru perlu menghargainya. Penjelasan singkat mengapa jawaban tersebut tidak relevan merupakan cara yang baik untuk menanggapi jawaban sedemikian itu. Jika siswa tersebut serius, dia akan memahami mengapa jawabannya tidak relevan.

Guru tidak perlu menjawab semua pertanyaan yang muncul di dalam diskusi. Tidak semua guru mempunyai kemampuan menjawab semua pertanyaan dengan tepat dan hati-hati. Yang lebih penting lagi, apabila seorang guru menjawab suatu pertanyaan, hal tersebut cenderung mengakhiri kegiatan intelektual yang mengawali pertanyaan tersebut. Jika seorang siswa bertanya, "Apakah potongan es ini akan mengambang/terapung di minyak tanah?", dan guru menjawabnya "ya", aktivitas belajar akan berhenti di situ. Tetapi apabila guru berkata " mengapa anda tidak mencobanya dan mencari jawabannya", guru benar-benar menciptakan suasana belajar yang aktif. Itulah salah satu keterampilan bertanya 
yang harus dikembangkan dan dimiliki oleh guru.

Pertanyaan -pertanyaan yang relevan dapat dipergunakan untuk mengawali kegiatan memecahkan masalah, secara kelompok atau individual. Kadang-kadang siswa yang berminat dapat diberi tugas secara berkelompok memecahkan masalah tertentu. Seringkali guru perlu menjelaskan kepada siswa yang berminat untuk memecahkannya di hari mendatang. Apakah kesempatan semacam ini akan diberikan oleh guru kepada siswanya, hal ini sangat bergantung pada macam masalah dan kemampuan guru untuk mempertimbangkan apakah kegiatan tersebut akan merupakan kegiatan diskusi yang bermanfaat.

Suatu diskusi kelas pada umumnya akan mengalami kemunduran setelah berlangsung beberapa menit. Sebagian besar siswa akan mengalami kesukaran untuk menfokuskan perhatiannya pada diskusi, sebab hanya seorang siswa yang dapat berbicara pada saat tertentu, sedangkan siswa-siswa yang lain hanya mendengarkan apa yang dikatakan oleh temannya. Semakin besar jumlah siswa dalam suatu kelompok diskusi, semakin sulit bagi seorang siswa ikut berperan aktif di dalam diskusi. Agar dapat mempertahankan perhatian siswa selama berlangsungnya diskusi, topik diskusi perlu sangat menarik bagi siswa. Yang sering terjadi di dalam suatu diskusi ialah hanya sedikit siswa yang terlibat secara aktif di dalam diskusi, sedangkan siswa yang lain hanya sedikit saja terlibat di dalam diskusi, atau bahkan tidak terlibat sama sekali di dalam diskusi. Guru harus tanggap terhadap kemungkinan terjadinya kebosanan pada siswa, yang dapat berakibat munculnya masalah disiplin kelas. Diskusi dalam waktu yang singkat pada umumnya lebih baik daripada diskusi yang berlangsung dalam waktu yang lama, karena dapat menghindarkan atau memperkecil kemungkinan timbulnya halhal yang mengarah pada munculnya masalah disiplin kelas.

\section{Pengkondisian Awal}

Diskusi mempunyai peran penting di dalam pembelajaran sains. Sayangnya, guru sains menggunakan istilah diskusi apabila mereka melakukan pembelajaran yang berbentuk ceramah, tanya jawab, menjelaskan prosedur yang harus dilakukan oleh siswa, dan bentuk kegiatan pembelajaran yang lain. Apabila seorang guru berkata: "Kita akan mendiskusikan pertumbuhan penduduk". Sebenarnya yang dimaksud oleh guru tersebut adalah "Saya akan menjelaskan kepada kalian topik perkembangan penduduk". (Kardi, S. 2010)

Selama berlangsungnya diskusi, siswa perlu bebas mengemukakan pendapatnya. Hal ini berarti bahwa siswa perlu mempunyai pengetahuan yang berkaitan dengan diskusi, agar dapat berperan serta secara aktif. Demikian pula halnya dengan guru, dia perlu mempunyai latar belakang pengetahuan yang berkaitan dengan topik diskusi dan mempunyai minat terhadapnya.

Tingkat partisipasi siswa di dalam diskusi kadarnya bermacam-macam, bergantung pada topiknya, kemampuan siswa di dalam kelompok diskusi, dan kesiapan psikologis siswa untuk membicarakan topik diskusi. Tingkat partisipasi siswa di dalam diskusi juga bergantung pada keterampilan guru untuk melaksanakan diskusi dengan berhasil. Misalnya kemampuan guru dalam mengorganisir pertanyaan dan melemparkannya kepada siswanya secara seimbang agar semua siswa dalam kelas trerlibat secara aktif. Siswa yang berpartisipasi sangat aktif dapat direm oleh guru dengan tanpa menyinggungnya dengan mengatakan dan memberi kesempatan kepada teman yang lain.

Siswa tidak dapat mendiskusikan topik secara mendalam, kecuali jika mereka tertarik dan mempunyai minat untuk memahami isi topik diskusi. Pemilihan topik diskusi perlu memperhatikan tingkat kematangan siswa. 
Anak-anak klas sekolah dasar memerlukan pembimbingan yang lebih dibandingkan dengan tingkatan yang lebih diatasnya. Sebagai contoh topik yang sesuai untuk siswa kelas 7 SMP belum tentu cocok untuk siswa kelas 8 SMP. Demikian pula untuk tingkat SMA dan tingkat mahasiswa. Oleh sebab itu guru atau Dosen perlu memilih topik diskusi dengan sangat berhati-hati sebelum guru mulai merencanakan suatu diskusi.

Kepribadian dan persiapan diskusi dapat mempengaruhi keberhasilan suatu diskusi. Guru yang bersifat otoriter dan sangat disiplin tidak akan menciptakan suasana diskusi yang bebas. Guru yang tidak membuat siswa merasa tertekan, menciptakan suasana diskusi yang bebas, dan dapat menahan untuk memberikan komentarnya sendiri, akan dapat melaksanakan diskusi dengan berhasil.

Guru harus mempunyai persiapan yang cukup agar dapat mengajukan pertanyaan-pertanyaan yang benar, dan dapat mengajukan permasalahan untuk didiskusikan siswa. Janganlah guru tidak mengerti apa-apa tentang bahan yang didiskusikan. Siswa akan terkesan bahwa guru tersebut tidak menguasai bahan yang didiskusikan dan metode diskusi akan dianggap siswa sebagai pelarian bahwa guru tersebut tidaklah mampu mengajar materi itu. Guru harus dapat merumuskan pertanyaan yang dapat dipahami oleh siswa dan dapat memotivasi mereka. Janganlah mematikan semangat siswa dan menyinggung perasaan.

Lingkungan fisik, tempat dilaksanakannya diskusi, juga sangat berpengaruh terhadap keberhasilan suatu diskusi. Suatu ruangan yang sempit dan panas, lagi pula tempat duduknya tidak nyaman, akan memberikan hasil diskusi yang tidak baik. Sebaliknya, suatu ruangan yang terang, udaranya segar, dan menarik, akan membuat siswa berpartisipasi secara aktif di dalam diskusi. Lingkungan yang mendukung akan berkontribusi terhadap hasil suatu diskusi.
Kegiatan belajar mengajar yang benar-benar menggambarkan diskusi kelas ialah kegiatan yang tidak dipengaruhi oleh opini guru, atau guru tidak mendikte jalannya diskusi. Jika tidak demikian, maka kegiatan belajar mengajar menjadi ceramah. Diskusi bebas sangat efektif untuk memunculkan permasalahan yang berkaitan dengan isu-isu ilmu baru, teknologi baru, problema baru maupun sosial. Diskusi bebas memberikan kesempatan kepada siswa untuk bertukar pikiran dengan sesama siswa sehingga mereka dapat mengambil kesimpulan sendiri, membuat penilaian sendiri, mengembangkan dan mengemukakan nilai-nilai yang dianutnya sendiri. Diskusi bebas merupakan cara yang baik untuk memperoleh rangkuman lisan dari siswa, yang dapat dimanfaatkan guru dalam perencanaan. Guru tetap berwawasan lebih luas dan jauh kedepan.

Diskusi yang baik memerlukan keterampilan yang khusus. Guru perlu mempunyai keterampilan untuk mempertahankan perhatian siswa pada pokok pembicaraan tertentu tanpa mengurangi minat mereka yang komentarnya tidak relevan dengan pokok pembicaraan. Kemampuan memfokuskan seperti ini guru perlu berlatih dan belajar karena tidak dapat muncul dengan sendirinya. Disamping itu, guru perlu juga mempunyai keterampilan untuk mengontrol situasi, agar diskusi tidak dikuasai oleh sekelompok siswa saja. Tegas dalam bertindak tetapi terkesan lowprofil oleh siswa.

\section{Mengorganisasikan Siswa}

Guru perlu menyadari bahwa diskusi yang baik tidak dapat dilaksanakan di sebarang tatanan kelas. Karena diskusi memerlukan interaksi dan pertukaran pendapat di antara siswa, jumlah siswa dalam suatu kelompok diskusi perlu dibatasi. Seorang guru yang terampil mungkin dapat melaksanakan diskusi dengan baik yang jumlah siswanya antara $15-20$ orang. Jumlah siswa yang terlalu 
banyak akan menghambat jalanya diskusi, para siswa tidak dapat berpartisipasi secara maksimum, dan diskusi berubah menjadi ceramah yang kadang-kadang diselingi oleh pertanyaan dan komentar siswa. Jumlah optimum siswa dalam suatu diskusi ialah antara 10 sampai dengan 20 orang. Jika jumlah siswa kurang dari 10 orang, pertukaran informasi antar siswa tidak akan intensif. (Kardi, 2010)

Agar pertukaran pendapat antar siswa dapat berlangsung dengan baik, tatanan tempat duduk siswa disarankan diatur secara melingkar, atau dengan tatanan yang mempermudah siswa untuk saling bertukar pendapat. Tatanan ruang perlu diatur agar suara siswa dapat didengar dengan jelas tanpa meninggikan nada suara, siswa dapat saling bertatap muka sehingga ekspresi muka setiap siswa dapat diamati dengan mudah dan jelas. Tatanan ruang penting untuk menciptakan lingkungan yang sesuai guna mengekspresikan pendapat dan mengajukan pertanyaan.

Sebagai ilustrasi guru berada di depan dan siswa mengelilingi meja atau bangku yang disusun kotak/melingkar saling berhadapan.

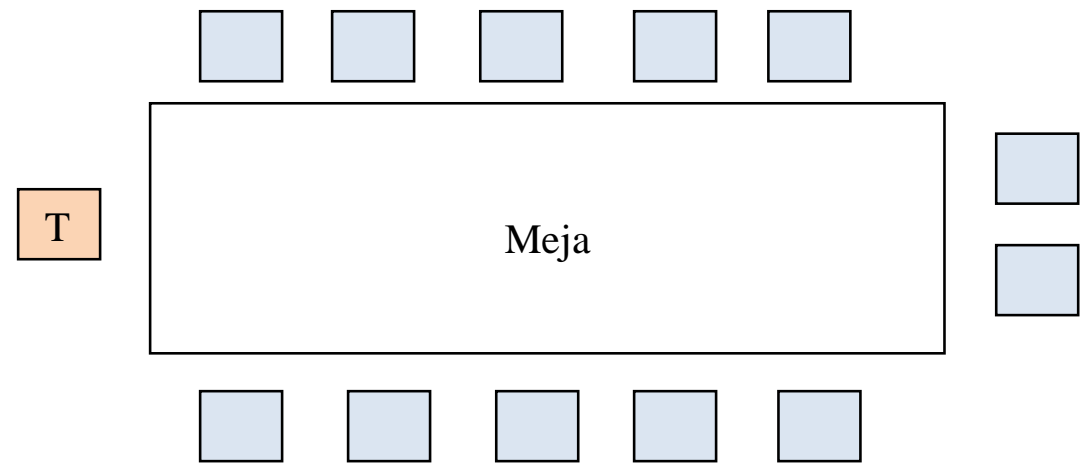

Jika guru merencanakan diskusi sebagai awal kegiatan inkuiri, disarankan agar tempat duduk disusun di sekitar meja demonstrasi, atau di tempat lain yang akan dipergunakan sebagai tempat diskusi.
Sebagai ilustrasi guru berada di tengah dan dikelilingi siswa yang dikelompokkan menjadi 4 kelompok seperti gambar di bawah ini.

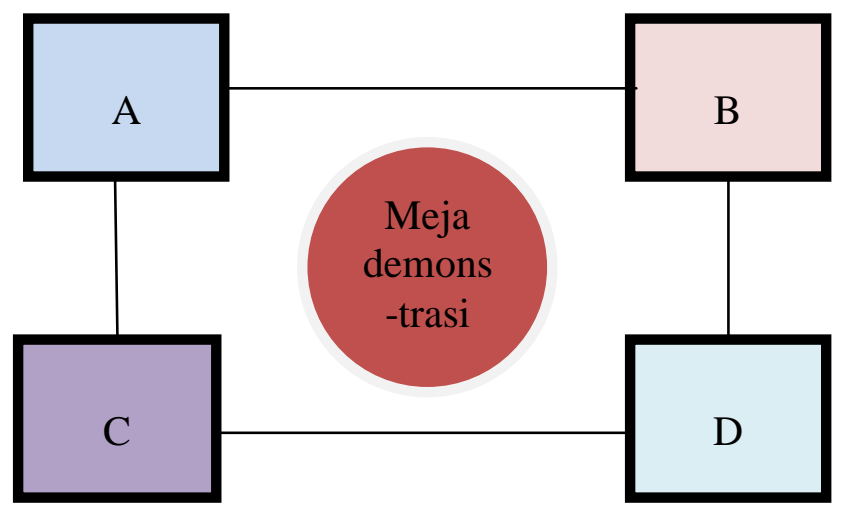

Tempat duduk dan perangkat demonstrasi oleh guru diatur agar memungkinkan terjadinya interaksi antara guru dengan siswa, dan alat-alat dapat diperlihatkan dengan jelas kepada siswa.
Jika guru menginginkan siswa melakukan percobaan sebelum diskusi, perlu disediakan perangkat yang jumlahnya cukup, untuk menghindarkan terjadinya 
keragu-raguan, hambatan, dan ketidakteraturan kegiatan. Dengan demikian siswa dapat bekerja dalam kelompok -kelompok kecil, yang kemudian dapat diorganisasikan kembali menjadi diskusi kelas.

Diskusi sebaiknya dilaksanakan di tempat yang memudahkan siswa untuk memperoleh referensi yang diperlukan. Tersedianya perpustakaan dan referensi laboratorium akan mempermudah pengumpulan informasi pada waktu yang tepat sesuai dengan tingkat kemajuan diskusi. Dengan demikian siswa akan menyadari bahwa penting sekali memperoleh data yang diperlukan agar diskusi dapat berlanjut.

Guru perlu memperhatikan diskusi pada waktu yang tepat dan meminta kepada siswa untuk membentuk kerja kelompok atau individual untuk mengumpulkan data, dan setelah itu diskusi kelas dapat dilanjutkan kembali. Mudahnya mengubah diskusi kelas menjadi kerja kelompok atau individual, atau sebaliknya, akan memungkinkan terjadinya diskusi yang bermanfaat antar siswa.

Sesi pembelajaran kelompok atau pembelajaran individual akan sangat bermanfaat apabila ada spesialis yang membantu diskusi. Spesialis ini mungkin guru lain atau anggota masyarakat yang menguasai benar topik diskusi yang sedang dibicarakan. Seorang guru seringkali menyadari bahwa tidak semua pertanyaan siswa dapat dijawab olehnya, dan peran serta seorang spesialis akan sangat membantunya.

Dari uraian tentang metode diskusi dapat disimpulkan bahwa keberhasilan suatu diskusi bergantung pada fleksibilitas guru, siswa, pengaturan lingkungan fisik, dan penjadwalan. Hambatan terhadap salah satu faktor tersebut akan mengurangi kefektifan diskusi.

\section{Mengawali Sesi Inkuiri}

Diskusi dapat dipergunakan untuk memotivasi siswa dalam menemukan sendiri informasi yang dipelajarinya.
Kegiatan tersebut akan efektif apabila siswa mengemukakan pertanyaan dan permasalahan yang menurut mereka bermanfaat untuk dipecahkan. Perhatikan uraian berikut ini.

Saya mengetahui bahwa di antara kalian ada yang merokok, kata Adi, seorang guru IPA, kepada para siswanya pada saat mengawali kegiatan kelas. Saya juga mengetahui bahwa kalian yang sekarang tidak merokok mungkin sekali akan merokok di kemudian hari. Saya percaya bahwa kalian telah mendengar argumentasi dari mereka yang menetang kebiasaan merokok. Sebenarnya, kalian yang merokok, dan mungkin di antara kalian yang tidak merokok, telah mengetahui bahwa produsen rokok perlu memberi peringatan kepada masyarakat tentang bahaya yang mungkin ditimbulkan oleh kebiasaan merokok. Marilah kita bahas argumentasi apa yang dikemukakan oleh mereka yang menentang kebiasaan merokok.

Pada beberapa menit berikutnya sejumlah siswa memberikan informasi yang benar dan yang kurang benar, yang telah mereka kumpulkan secara tidak langsung melalui bacaan dan interaksinya dengan anggota masyarakat dan temantemannya. Akhirnya sebagian besar siswa berkesimpulan bahwa mereka belum atau benar-benar tidak memahami topik diskusi dan berkeinginan untuk mempelajarinya lebih lanjut. Seorang siswi mengatakan kepada gurunya bahwa ia ingin mengetahui lebih lanjut tentang bahaya yang ditimbulkan oleh kebiasaan merokok, dan minta kepada guru menunjukkan literatur tentang hal tersebut. Siswa-siswa yang lainpun mempunyai keinginan yang sama. Adi kemudian membagikan daftar referensi mengenai akibat yang dapat timbul karena merokok. Adi menugasi semua siswa untuk membaca referensi tersebut dan berupaya membaca buku yang lain.

Adi kemudian mengulang kembali apa yang telah dikatakan oleh salah seorang siswanya bahwa ayahnya telah 
berhenti merokok karena dalam paruparunya tumbuh tumor. Siswa yang lain mengatakan bahwa pamannya telah meninggal dunia karena menderita kanker paru-paru, yang menurut dokter yang merawatnya diakibatkan oleh kebiasaan merokok. Siswa yang lain memberitahu temannya tentang contoh-contoh kelainan lain yang disebabkan oleh kebiasaan merokok. Diskusi akhirnya sampai pada kesimpulan perlunya bertanya kepada dokter-dokter terkait untuk memperoleh penjelasan tentang gangguan kesehatan karena merokok.

Diskusi diakhiri dengan membuat perencanaan. Permasalahan dirumuskan dengan jelas, beberapa orang siswa memberikan saran tentang prosedur yang dapat dilakukan untuk mengumpulkan data guna memecahkan masalah. Sejumlah siswa mengusulkan bahwa mereka perlu membaca buku lebih dulu, sebelum melakukan pengumpulan data, sedangkan beberapa siswa yang lain menyatakan akan mewawancarai dokter, orang tua, petugas kesehatan yang lain, untuk mengetahui lebih lanjut gangguan kesehatan yang disebabkan oleh kebiasaan merokok. Adi menyadari bahwa ia telah memotivasi siswa dan meminta kepada mereka untuk mempelajari buku-buku yang telah disarankan sebagai acuan untuk persiapan lebih lanjut.

Adi memilih topik diskusi yang sangat baik, sebab banyak para remaja yang dihadapkan pada masalah merokok. Kebanyakan dari mereka tidak mau menerima nasehat orang tua atau guru mereka agar tidak merokok, tetapi mereka selalu bersedia untuk mendiskusikan masalah yang sedang mereka hadapi. Topik yang dikemukakan oleh Adi adalah salah satu topik yang para siswa mempunyai latar belakang pengetahuan yang cukup untuk mendiskusikannya dengan berhasil. Beberapa orang siswa, langsung atau secara tidak langsung, pernah berhadapan dengan masalah merokok, sehingga topik tersebut benarbenar sangat cocok untuk didiskusikan. Di samping itu, para siswa juga menyadari bahwa mereka tidak mempunyai pengetahuan dan data yang cukup untuk memahami masalah tersebut secara mendalam. Pendapat-pendapat yang kontroversial seringkali muncul, yang memotivasi siswa untuk menelitinya lebih lanjut.

Isu-isu yang kontroversial seperti penggunaan narkoba, aborsi, penyakit AIDS, merupakan topik yang baik untuk diskusi mengidentifikasi masalah. Hal-hal yang saat ini menarik banyak anggota masyarakat juga baik untuk diskusi semacam itu.

Tidak selalu baik mengawali suatu topik dengan diskusi. Siswa tidak selalu mempunyai latar belakang pengetahuan dan minat yang cukup untuk melakukan diskusi yang bermanfaat pada awal pembelajaran. Pendekatan lain untuk membangkitkan minat dan motivasi dapat dimanfaatkan, yang pada umumnya lebih efektif. Guru perlu mempersiapkan pengetahuan awal siswa yang diperlukan agar diskusi dapat mencapai tujuan.

\section{Penutup}

Dari uraian tentang metode diskusi dapat disimpulkan bahwa keberhasilan suatu diskusi bergantung pada fleksibilitas guru, aktivitas siswa, pengaturan lingkungan fisik, dan penjadwalan. Hambatan terhadap salah satu faktor tersebut akan mengurangi keefektifan diskusi. Pemilihan topik-topik yang menarik, kontroversial dan isu yang sedang berkembang mendukung keberhasilan dalam diskusi. 


\section{Referensi}

1. Corebima, A.D., Susilo, H., Hedi Sutomo. 2005. Pengembangan Model Pembelajaran IPA Biologi SMP Konstruktivistik Kontekstual Berorientasi Life Skill dengan Pola PBMP di Kota dan Kabupaten Malang. Laporan Penelitian Akhir Tahun 2005. Kementrian Riset dan Teknologi Lembaga Ilmu Pengetahuan Alam.

2. Maududi, M. Ali. 2002. Pengaruh Penerapan Pembelajaran dengan Pola Pemberdayaan Berpikir Melalui Pertanyaan (PBMP) Terhadap Keaktifan dan Hasil Belajar Siswa Kelas 1 SLTPN 2 Krucil Probolinggo. Skripsi
3. Gularso, W. 2008. Diskusi sebagai sarana pengembangan keterampilan kognitif, afektif dan sossial. Makalah: Jogjakarta. UNY

4. Jatmiko, Budi. 2003. Contextual Teaching And Learning (CTL) Dan Pembelajaran Dalam Kurikulum Berbasis Kompetensi (KBK). Makalah. Surabaya: Unesa

5. Kardi, Soeparman. 2010. Ceramah, Resitasi dan Diskusi. Bahan ajar pendidikan sains Unesa.

6. Tjokrodiharjo. 2005. Model Pembelajaran Diskusi. Pusat Sains dan Matematika Sekolah. Unesa

7. Gularso, W. 2008. Diskusi sebagai sarana pengembangan keterampilan kognitif, afektif dan sossial. Makalah: Jogjakarta. UNY 